\title{
LIFE HISTORIES OF NORTH AMERICAN GEOMETRIDAE-LIX.
}

\author{
BY HARRISIN G. DYAR, WASHINGTON, D. C.
}

\section{Eucblaena astfitusaria Walker.}

Egg. Elliptical, well flattened, one end depressed, truncation rounded, not very obvious. Surface dimly hexagonally reticulate, the cell areas rather deep and pronounced but not sharp and all overlaid and obscured by fine granules of shagreen. Towards the large end the pores at the angles of the reticulations are marked by large, distinct, rounded white elevations, but these become small towards the center of the egg and are lacking on the small end and the flat sides. Truncation reticular without white elevations. Bluish green, frosted by the white dots, turning bright red. Size $\mathrm{I} \times .6 \times .5 \mathrm{~mm}$.

Stage l. Head brownish luteous, the sutures dark. Body moderate, subdorsal and ventral broad red brown stripes, the subdorsal pair fused on joints ro-r 3 and marked in pale on the cervical shield. Sides white; abdominal feet stained with red, thoracic ones luteous.

Stage II. Fread rounded bilobed, whitish, clypeus and epistoma white, all the sutures dark brown; two parallel rows of gray dottings over the iobes; width $.55 \mathrm{~mm}$. Body slender, greenish white; broad subdorsal bands joining posteriorly, dotted on joint 2 , and broad ventral band purple brown. Thoracic feet brownish black, the abdominal ones reddish. Tubercules pale, setae black, both minute.

Stage III. Head oblique, flat before, lobes full; whitish with vertical rows of brown dots; and band acrass the bases of the antennx; width $1 \mathrm{~mm}$. Body moderate, slightly flattened, tubercles raised; dorsum brown, darker posteriorly on the segments, a geminate dotted dorsal line pale filled; sub-ventral fold white, subventer brown, venter dark purplish brown with fine geminate medioventral pale line. Small segmentary black subventral spots under the white fold. Feet pale: tubercles small, black; setae minute.

Stage $I V$. Head widest below, slightly bilobed, clypeus depressed; gray, spotted with black heaviest on the lower angles of the lobes and across above the mouth; a pale streak on the side, width $1.5 \mathrm{~mm}$. Body moderate, slaty gray, slightly streaked. Tubercles ii of joints 5, 8, 9 and 12 elevated, papillose, black, with black subdorsal blotches beside them, present but less distinct on the other segments. A broken, diffuse white band along the sub-ventral fold. Abdominal feet whitish outwardly, lined with black in front. Subdorsal, lateral and suprastig. matal pale lines indicated.

Stage V. Head round, somewhat quadrately bilobed; whitish gray mottled with darker, a black patch each side of the clypeus below and across above the mouth and on bases of antennx, width $2.3 \mathrm{~mm}$. Body moderate, tubercle ii raised and marked in black, especially on joints 5 and 11. Ashen gray with traces of waved white lines; dorsum of joints 5, 6,7 and 8 washed in whitish, sides with irregular biack marks, whitish intersegmental washings on the subventral fold; foot of joint to whitish, the others gray. Feet of joint 4 erected, the others appressed. The resemblance is to bark, all the markings being illy defined.

Eggs June a , mature larva August 6, single brooded with hibernation in the pupa. Larvæ from Kaslo, Brütish Columbia. 

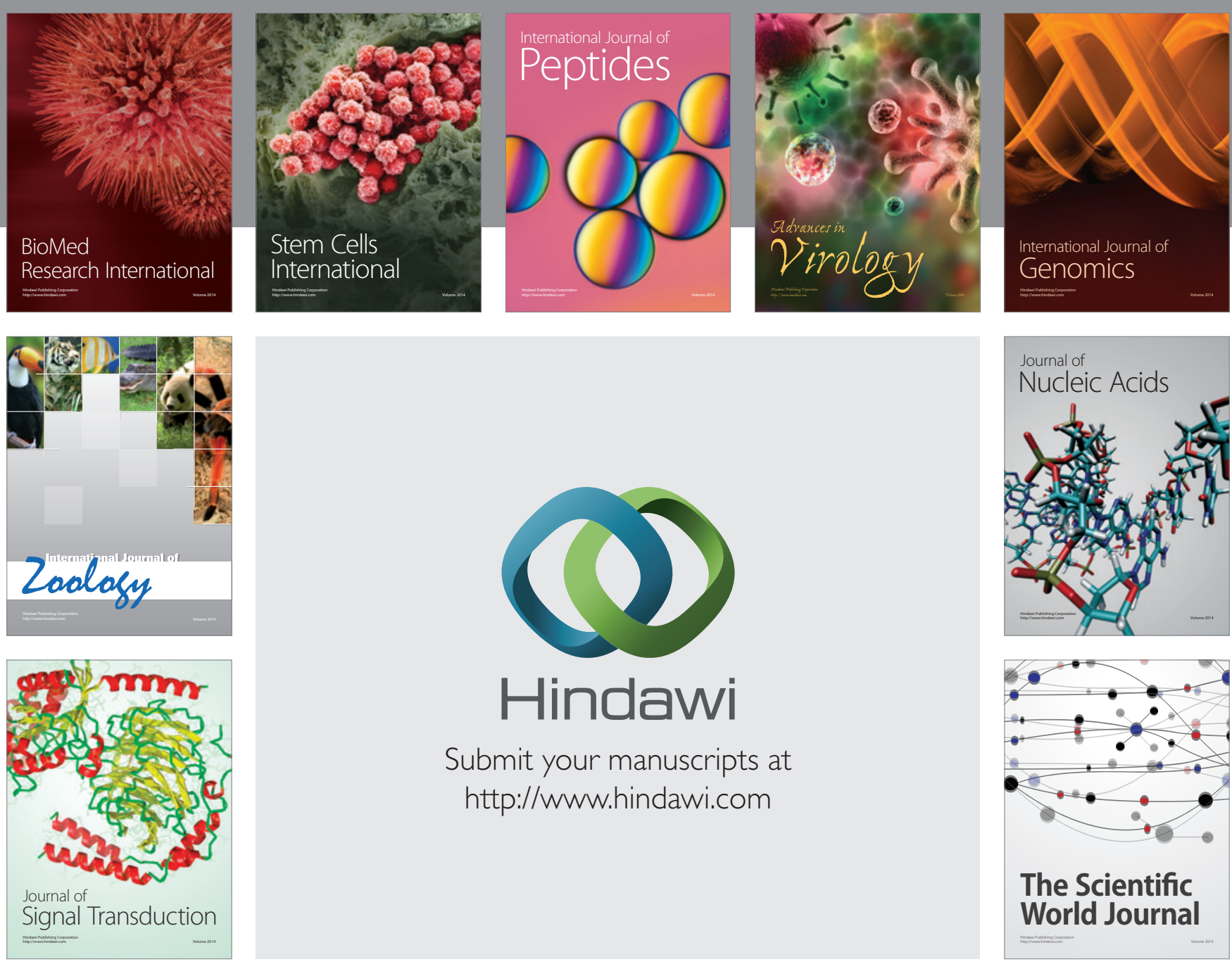

Submit your manuscripts at

http://www.hindawi.com
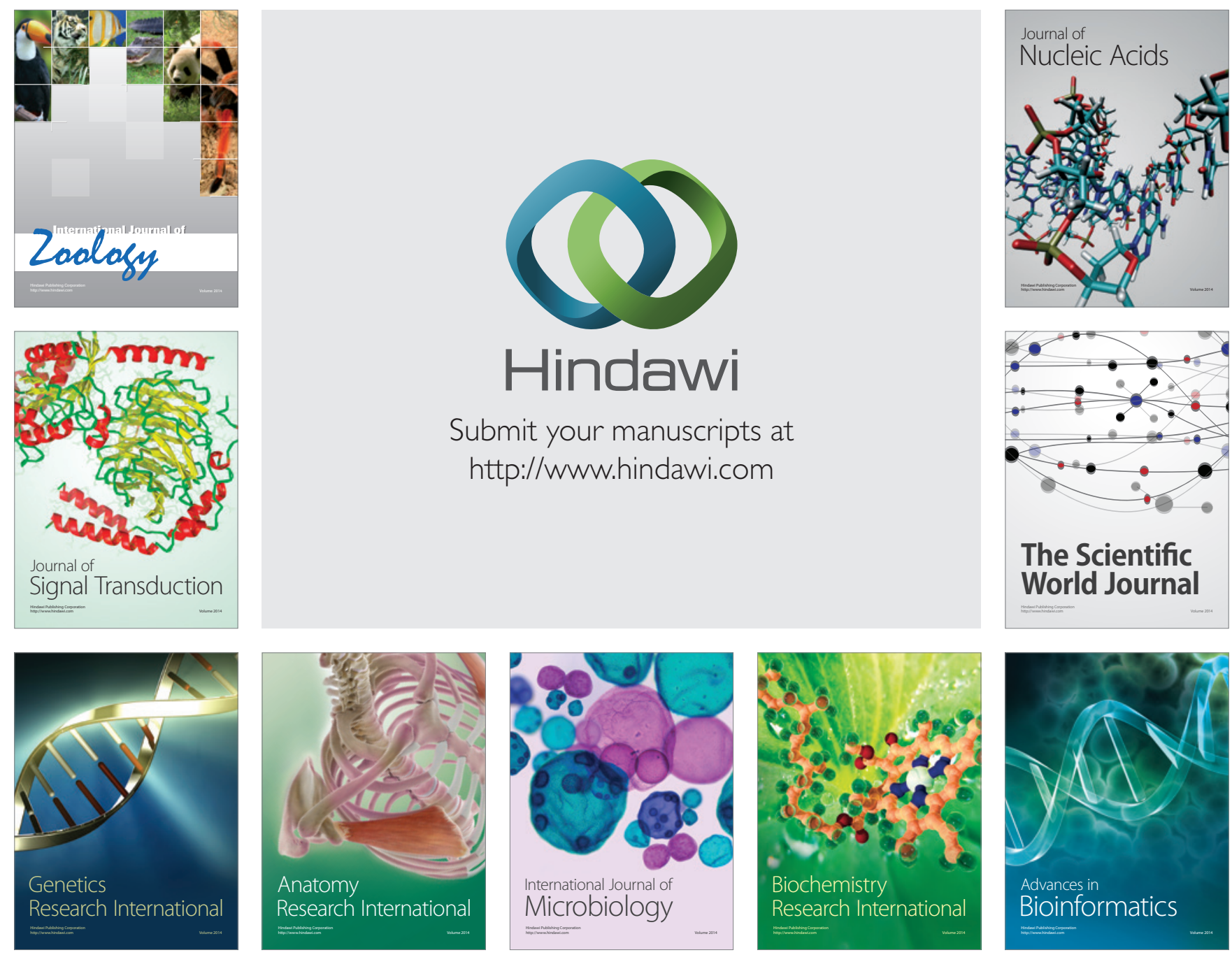

The Scientific World Journal
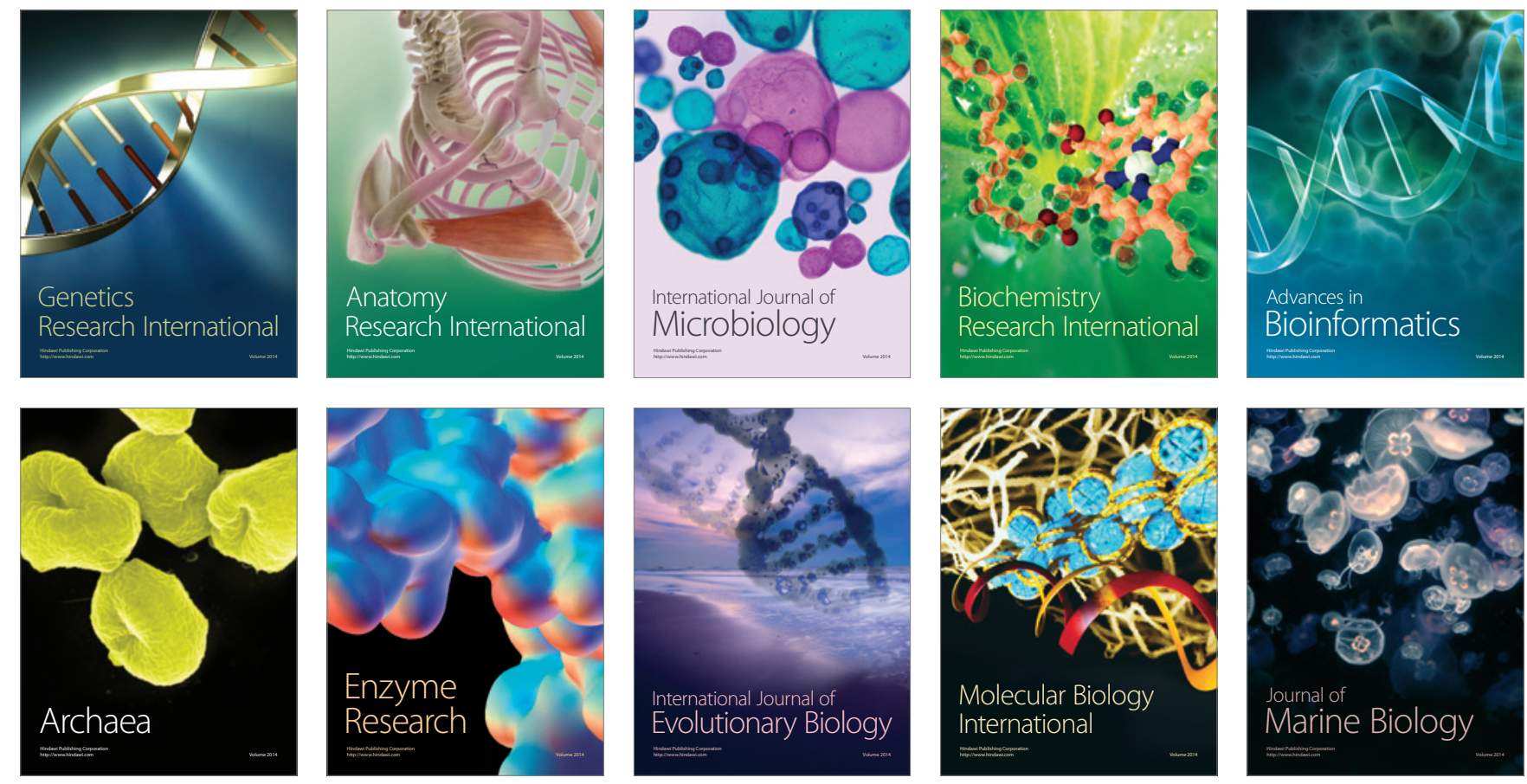